University of Nebraska - Lincoln

DigitalCommons@University of Nebraska - Lincoln

Faculty Papers and Publications in Animal

Science

Animal Science Department

August 1987

\title{
GROWTH PERFORMANCE FOR FOUR BREEDS OF SWINE: CROSSBRED FEMALES AND PUREBRED AND CROSSBRED BOARS
}

D. G. McLaren

Oklahoma State University, Stillwater

D. S. Buchanan

Oklahoma State University, Stillwater

R. K. Johnson

University of Nebraska-Lincoln, rjohnson5@unl.edu

Follow this and additional works at: https://digitalcommons.unl.edu/animalscifacpub

Part of the Animal Sciences Commons

McLaren, D. G.; Buchanan, D. S.; and Johnson, R. K., "GROWTH PERFORMANCE FOR FOUR BREEDS OF SWINE: CROSSBRED FEMALES AND PUREBRED AND CROSSBRED BOARS" (1987). Faculty Papers and Publications in Animal Science. 44.

https://digitalcommons.unl.edu/animalscifacpub/44

This Article is brought to you for free and open access by the Animal Science Department at DigitalCommons@University of Nebraska - Lincoln. It has been accepted for inclusion in Faculty Papers and Publications in Animal Science by an authorized administrator of DigitalCommons@University of Nebraska - Lincoln. 


\title{
GROWTH PERFORMANCE FOR FOUR BREEDS OF SWINE: CROSSBRED FEMALES AND PUREBRED AND CROSSBRED BOARS ${ }^{1}$
}

\author{
D. G. McLaren ${ }^{2}$, D. S. Buchanan ${ }^{3}$ and R. K. Johnson ${ }^{4}$ \\ Oklahoma State University \\ Stillwater 74078
}

\begin{abstract}
Purebred and two-breed cross $\left(F_{1}\right)$ boars were mated to $F_{1}$ females to produce all possible three- and four-breed cross pigs involving the Duroc, Yorkshire, Landrace and Spotted breeds. Individual postweaning average daily gain (ADG), age at $100 \mathrm{~kg}$ (AGE) and probed backfat thickness at $100 \mathrm{~kg}$ (BF) data were collected on 3,456 pigs. A total of 213 pens with an average of 15.58 pigs per pen was evaluated for postweaning feed-to-gain ratio (F/G) and average daily feed consumption (ADF). Genotype $X$ environment interactions, specifically breed $X$ year-season farrowed and breed $x$ parity (for ADG), were found to be highly significant. Certain results, however, were reasonably consistent across environments. Duroc-sired pigs grew more efficiently than other sire breed groups $(3.11$ vs $3.21 \mathrm{~F} / \mathrm{G})$, although there were no significant differences in ADF between sire groups. Duroc-sired pigs had less BF than other three-breed cross pigs, based upon within breed of dam comparisons, suggesting differences in composition between the more efficient Duroc-sired pigs and other breed groups. Landrace-sired pigs were fatter than other sire groups. No real differences between crossbred-sired pigs and the average of contemporary purebred-sired pigs were apparent for F/G, ADF, ADG, AGE or BF. Assuming paternal heterosis to be zero, these results suggested recombination effects to be negligible for postweaning performance traits. Apart from via direct genetic effects, mating crossbred rather than purebred boars to females of different breeding should have little or no impact on feedlot performance of offspring produced. (Key Words: Pigs, Crossbreds, Growth Rate, Feed Conversion Efficiency, Genotype Environment Interaction.)
\end{abstract}

\section{Introduction}

Interest in the use of crossbred boars for market hog production has arisen due to the expectation that such boars will be hardier and more vigorous than purebreds and possess greater libido and higher fertility. Consequently their use might improve breeding herd efficiency in commercial operations.

Literature reports of 6 to $20 \%$ improvement in conception rates from using crossbred vs purebred boars appear to be the result of accelerated maturity in the crossbreds (Wilson

\footnotetext{
${ }^{1}$ Manuscript 4956 of the Oklahoma Agr. Exp. Sta., Oklahoma State Univ., Stillwater 74078 .

${ }^{2}$ Present address: Anim. Sci. Dept., Univ. of Illinois, 126 Anim. Sci. Lab., 1207 W. Gregory Dr., Urbana 61801.

${ }^{3}$ Dept. of Anim. Sci.

${ }^{4}$ Present address: Anim. Sci. Dept., Univ. of Nebraska, 223 Marvel Baker Hall, Lincoln 68583.

Received March 3, 1986.

Accepted July 24, 1986.
}

et al., 1977; Conlon and Kennedy, 1978; Anderson et al., 1981; Buchanan and Johnson, 1984). No real differences between purebred and crossbred boars for sow productivity, or for growth and carcass characteristics of progeny, have been demonstrated (Rempel et al., 1964; Lishman et al., 1975; Fahmy and Holtmann, 1977; Conlon and Kennedy, 1978; Kennedy and Conlon, 1978; Anderson et al., 1981; Buchanan and Johnson, 1984).

Considerable data involving the numerically dominant Yorkshire, Duroc and Hampshire breeds exists (Johnson, 1980). Períormance of the Spotted and American Landrace breeds is poorly documented, despite their accounting for $21 \%$ of official transfers involving the eight major United States breeds in 1979 and 1980 (Hayenga et al., 1985). Experimental data involving these breeds is required to evaluate their utility in efficient pork production systems.

The objective of this study was to evaluate growth performance and feed conversion efficiency for three- and four-breed cross pigs 
involving the Duroc, Yorkshire, Landrace and Spotted breeds. In addition to estimating the effect of crossbred vs purebred boars for these traits, relative performance of the four breeds in terminal crossbreeding systems was compared.

\section{Materials and Methods}

A project aimed at evaluating purebred and crossbred performance of the Duroc, Yorkshire, Landrace and Spotted breeds of swine was carried out at the Oklahoma Agricultural Experiment Station between 1976 and 1979. As part of this project, three- and four-breed cross litters were produced over five consecutive farrowing seasons between 1977 and 1979 at the USDA Southwest Livestock and Forage Research Station, El Reno, Oklahoma. Postweaning performance records on 1,339 fourbreed cross and 2,117 three-breed cross pigs were available for analysis.

Experimental Procedure. Seedstock for the three- and four-breed cross phase of the experiment was produced at the Oklahoma State University Experimental Swine Farm at Stillwater by mating purebred Duroc, Yorkshire, Landrace and Spotted males and females in all possible combinations to produce purebred and two-breed cross offspring. Establishment and management of the purebred herds have been discussed by Hutchens et al. (1982) and Gaugler et al. (1984). Foundation boars and gilts of each breed were obtained from several different sources, and semi-annual introduction of at least one new boar of each breed was practiced in order to maintain a broad genetic base in the purebred herds. Each purebred herd consisted of seven to nine boars and 30 to 35 females.

Boars with high index scores (based on age and probed backfat at $100 \mathrm{~kg}$ ) were selected from each breed group at Stillwater and transported to El Reno to be used as herd sires each season. All boars used in commercial production are the product of some type of selection, and the method used in this experiment represented recommended practice for terminal sire selection. Similar selection pressure was applied in all breed groups and selection method should therefore have little, if any, effect on interpretation of results. Crossbred gilts were sent to El Reno upon detection of estrus. Breeding stock from each breed group was used, but reciprocal crosses were combined for all analyses.

Generally, three boars from each breed group were used at El Reno each season, although for some breeds in some seasons as few as two and as many as five different boars were used. Purebred boars were mated to crossbred females to produce all possible three-breed cross litters, and crossbred boars were mated to crossbred females to produce four-breed cross litters. The breeding season extended over an 8-wk period starting in mid May and mid November each year. The total number of litters farrowed per breed group is given in table 1 . Only gilts were farrowed in the first season (fall 1977). In subsequent seasons about one-half the litters were from second

TABLE 1. NUMBER OF LITTERS FARROWED AND PIGS COMPLETING GAIN TEST BY BREED GROUPa

\begin{tabular}{|c|c|c|c|c|c|c|c|}
\hline \multirow{2}{*}{$\begin{array}{l}\text { Breeding of } \\
\text { sire }\end{array}$} & \multirow{2}{*}{$\begin{array}{l}\text { No. of } \\
\text { siresc }\end{array}$} & \multicolumn{6}{|c|}{ Breeding of dam $b$} \\
\hline & & D-Y & D-L & D-S & $Y-\mathbf{L}$ & Y-S & L-S \\
\hline Duroc (D) & 17 & & & & $22(168)$ & $26(163)$ & $28(212)$ \\
\hline Yorkshire (Y) & 17 & & $27(192)$ & $23(151)$ & & & $24(189)$ \\
\hline Landrace (L) & 15 & $20(146)$ & & $25(189)$ & & $23(150)$ & \\
\hline Spotted (S) & 14 & $27(189)$ & $26(187)$ & & $23(181)$ & & \\
\hline Crossbred & 89 & $29(213)$ & $35(268)$ & $34(242)$ & $34(250)$ & $30(174)$ & $31(192)$ \\
\hline
\end{tabular}

\footnotetext{
${ }^{a}$ Number of pigs in parentheses.

${ }^{b}$ Reciprocal crosses combined (i.e., D-Y represents DXY and YXD). For each dam breed group, crossbred boars represented $F_{1}$ 's involving the two breeds not included in the $F_{1}$ dam.

$c_{n=15}$ for each crossbred sire group except for $Y$-L sires, where $n=14$.
} 
parity sows and one-half from gilts. A total of 309 gilt and 178 sow litters was analyzed in this study.

Litters were farrowed in a barn equipped with crates and slatted floors. Sows and litters were moved to a nursery 3 to $7 \mathrm{~d}$ post-farrowing, where they remained in individual pens until weaning at approximately $6 \mathrm{wk}$ of age. Creep feed was made available and male pigs were castrated at 3 wk of age. Buchanan and Johnson (1984) reported reproductive performance for this phase of the experiment.

Pigs were moved to one of two confinement finishing barns for gain test approximately $2 \mathrm{wk}$ postweaning, and penned in groups of 12 to 20 pigs per pen by breed of sire (Duroc, Yorkshire, Landrace, Spotted or Crossbred). Possible effects associated with differences in pen stocking density and level of competition at the feeder were examined by including number of pigs per pen in the statistical analyses. A 7-d adjustment period was allowed before pigs were weighed on test at approximately 9 wk of age. A $16 \%$ crude protein corn- or sorghum grainbased diet was fed ad libitum until average pig weight per pen was approximately $54 \mathrm{~kg}$. A $14 \%$ crude protein diet was fed ad libitum for the duration of the test period.

Pigs were weighed off-test weekly at ap* proximately $100 \mathrm{~kg}$, at which time probed backfat thickness was measured. Measurements were taken at the first rib, last rib and last lumbar vertebra and averaged. Average daily gain, age and backfat records were adjusted to a $100-\mathrm{kg}$ basis. Total gain, total feed consumed and total days on test were obtained for each pen. During the five seasons of this phase of the experiment, 80 four-breed cross pens and 133 three-breed cross pens were tested.

Statistical Analyses. The following linear model, with zero-sum restrictions on fixed parameters, was assumed in analyzing pen data (feed-to-gain ratio and average daily feed consumption):

$$
y_{i j k l}=\mu+B_{i}+F_{j}+(B F)_{i j}+R_{k}+(F R)_{j k}+e_{i j k l},
$$

where

$y_{\mathrm{ijk} 1}=$ an observable random variable;

$\mu=$ an unknown constant;

$B_{i}=$ fixed effect of the $i$ th sire breed group, $\mathrm{i}=1, \ldots, 5$;

$F_{j}=$ fixed effect of the $j^{\text {th }}$ farrowing season, $j=1, \ldots, 5$;
$R_{k}=$ fixed effect of the $k^{\text {th }}$ finishing barn, $\mathrm{k}=1,2$;

$(B F)_{i j},(F R)_{j k}=$ interaction terms and

$e_{i j k l}=$ random residual effect, e's assumed iid $\mathrm{N}\left(0, \sigma_{\mathrm{e}}^{2}\right)$.

Preliminary analyses revealed the remaining two-factor and all three-factor interactions to be nonsignificant $(P>.20)$. Number of pigs per pen, included as a covariable in preliminary models, failed to approach significance $(P>.50)$. These terms were therefore not included in the final model.

The model assumed, again with zero-sum restrictions on fixed parameters, in analyzing postweaning average daily gain, age at $100 \mathrm{~kg}$ and probed backfat thickness at $100 \mathrm{~kg}$ was:

$$
\begin{gathered}
y_{i j k m n o}=\mu+B_{i}+F_{j}+(B F)_{i j}+S_{m} \\
+P_{n}+(B P)_{i n}+l_{k i j}+e_{i j k m n o}
\end{gathered}
$$

where

$\mathrm{y}_{\mathrm{ijkmno}}=\mathrm{an}$ observable random variable;

$\mu=$ an unknown constant;

$B_{i}=$ fixed effect of the $k^{\text {th }}$ breed of pig, $i=1, \ldots, 18$;

$F_{j}=$ fixed effect of the $j^{\text {th }}$ farrowing season, $\mathrm{j}=1, \ldots, 5$;

$S_{m}=$ fixed effect of the $k^{\text {th }}$ sex, $k=1,2$;

$P_{n}=$ fixed effect of the $n^{\text {th }}$ parity, $\mathrm{n}=1,2$;

$(B F)_{i j},(B P)_{\text {in }}=$ interaction effects;

$1_{k i j}=$ random effect of the $k^{\text {th }}$ litter nested within the ijth breedfarrowing season subclass, l's assumed iid $\mathrm{N}\left(0, \sigma_{1}^{2}\right)$ and

$e_{\mathrm{ijkmno}}=$ random residual effect, e's assumed iid $\mathrm{N}\left(0, \sigma_{\mathrm{e}}^{2}\right)$.

In the absence of a hierarchical design (different sires were used each season, but a number of females were retained for a second parity), it was practical to include either sires or litters in the model. Both produced similar results, but including litters was considered to describe the data more adequately.

The estimated ratio of the residual to litter components of variance $(4.26$, assuming heritability of .38 for all three traits and that $\sigma_{1}^{2}=$ one-half the additive genetic variance) was included in litter equations, which were then absorbed. Where ratios of the variances are known, solutions are generalized least-squares 
estimates of fixed effects (Harvey, 1982). Additional fixed interactions, nonsignificant in preliminary analyses $(P>.10)$, were not included in the final model. All analyses were computed using the SAS Harvey procedure (Joyner, 1983).

Paternal heterosis and recombination effects were jointly estimated as the deviation of the four-breed cross least-squares mean from the average of corresponding three-breed cross means. Based upon Dickerson's $(1969,1973)$ crossbreeding effects model, the expected value of this difference equals paternal heterosis plus one-quarter of the recombination effect. One-half of the gametes from both parents are recombinant in the four-way cross (assuming linkage equilibrium), vs only one-quarter when the sire is purebred, resulting in the coefficient of one-quarter. Significance was tested using the $t$ statistic.

\section{Results}

Pen Feed Data. Mean squares and significance of F-statistics for effects in the model of pen data are given in table 2. Breed of sire and year-season $x$ breed of sire were significant for feed-to-gain ratio, but not for average daily feed consumption.

Feed-to-gain ratio, averaged across yearseasons, was $3.11 \pm .02$ for Duroc-sired pens, $3.20 \pm .03$ for Yorkshire-, $3.20 \pm .02$ for crossbred-, $3.22 \pm .03$ for Landrace- and $3.23 \pm$ .02 for Spotted-sired pens. Given the significant interaction, breed of sire $x$ year-season least- squares means are illustrated graphically in figure 1. Duroc-sired pigs were consistently more efficient than other breed groups throughout the experiment. The significant breed $x$ year-season interaction was due to similarity of sire breed groups in the fall 1977 and spring 1979 farrowings and to changes in rank of breed groups other than the Duroc in other year-seasons (figure 1). This interaction could have been caused in part by the fact that a new sample of sires was used each breeding season. Such sampling would result in the average genetic merit of boars of each breed changing between year-seasons. While causing an interaction, this would not invalidate comparison of breed differences averaged across year-seasons. However, another likely important factor was that pigs farrowed in the fall of 1977 suffered badly from atrophic rhinitis, and those farrowed in the spring of 1979 from pneumonia. It is conceivable that stress of disease reduced appetite and thus prevented expression of potential differences in feed conversion efficiency between breed groups in these two year-seasons. Average daily feed consumption was significantly lower in the fall of 1977 , fall of 1978 and spring of 1979 seasons than in the spring of 1978 and fall of $1979(2.00,2.09$ and $2.08 \pm .03 \mathrm{~kg} / \mathrm{d}$ vs $2.31 \pm .03$ and $2.30 \pm .04$ $\mathrm{kg} / \mathrm{d}$, respectively).

Analyzing the data by year-season revealed significant differences between breeds of sire in the spring 1978 and the fall 1979 farrowed pigs, and differences approached significance in the fall 1978 pigs. Duroc-sired pens were

TABLE 2. LEAST-SQUARES ANALYSES OF VARIANCE FOR PEN DATA

\begin{tabular}{lrcc}
\hline & & & Mean squares \\
\cline { 3 - 4 } Source & df & F/G & ADFb \\
\hline Breeding of sire (BOS) & 4 & $.08087^{* *}$ & .04447 \\
Year-season farrowed (YRS) & 4 & $.04814^{*}$ & $.69471^{* *}$ \\
Barn & 1 & $.12246^{*}$ & .01156 \\
YRS X Barn & 4 & $.03675^{\dagger}$ & .00979 \\
YRS X BOS & 16 & $.03365^{*}$ & .02902 \\
Residual & 183 & .01867 & .03341 \\
\hline
\end{tabular}

\footnotetext{
${ }^{a}$ Feed-to-gain ratio.

${ }^{b}$ Average daily feed intake, $\mathrm{kg} \cdot \mathrm{pig}^{-1} \cdot \mathrm{d}^{-1}$.

${ }^{+} \mathrm{P}<\mathrm{10}$.

* $\mathrm{P}<.05$.

* * $\mathrm{P}<.01$.
} 


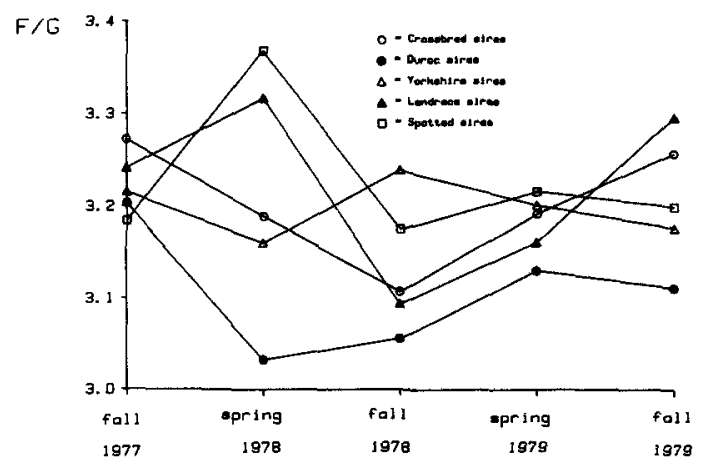

Figure 1. Feed-to-gain ratio (F/G) for purebredand crossbred-sired pens by year-season farrowed.

significantly more efficient than both Landraceand Spotted-sired pens in the spring 1978 farrowed group $(3.03 \pm .05$ vs $3.32 \pm .06$ and $3.37 \pm .05$, respectively), and more efficient than Landrace-sired pens in the fall 1979 farrowed group (3.11 \pm .06 vs $3.30 \pm .08$ ).

Comparing average feed efficiency for purebred-sired pens to that for crossbred-sired pens revealed no significant difference in any individual year-season, or overall. Average differences were $.015 \pm .020$ for feed-to-gain ratio and $-.005 \pm .027$ for average daily feed intake. Mating two-breed cross rather than purebred males to females of different breeding would therefore be expected to have little or no impact on subsequent feed conversion efficiency of offspring produced, other than via direct breed effects.

Breed of sire was not significant for average daily feed consumption (table 2). Differences in feed conversion efficiency were therefore not associated with differences in average daily feed consumption. Duroc-sired pigs had lower backfat probes than other sire groups (table 4), suggesting that differences in composition existed between the more feed efficient Durocsired pigs and other breed groups.

Genotype $x$ Environment Interactions. Mean squares and significant of F-statistics for postweaning average daily gain, age and probed backfat thickness at $100 \mathrm{~kg}$ are given in table 3 . The breed $x$ parity interaction was highly significant for average daily gain, approached significance for age at $100 \mathrm{~kg}$, but was not significant for probed backfat. The breed $x$ year-season farrowed interaction was highly significant for all three traits. Significant breed $x$ year and(or) season interactions in pigs have been reported for growth traits by a number of researchers, although other studies have found such interactions to be nonsignificant (McLaren, 1985).

Many factors undoubtedly contributed to year-season effects, but fluctuating disease status, seasonal temperature differences and sampling of sires were all probably important. Comparing breed group performance in individual year-seasons decreases precision and would restrict inference to populations under the same

TABLE 3. GENERALIZED LEAST-SQUARES ANALYSES OF VARIANCE FOR GAIN TEST DATA

\begin{tabular}{|c|c|c|c|c|}
\hline \multirow[b]{2}{*}{ Source $^{a}$} & \multirow[b]{2}{*}{ df } & \multicolumn{3}{|c|}{ Mean squares } \\
\hline & & $\mathrm{ADG}^{\mathrm{b}}$ & $\mathrm{AGE}^{\mathrm{C}}$ & $\mathrm{BF}^{\mathrm{d}}$ \\
\hline Breed group & 17 & $.01567 * *$ & $451.1 * *$ & $58.49 * *$ \\
\hline Year-season farrowed (YRS) & 4 & $.19218^{* *}$ & $9,572.3 * *$ & $598.95 * *$ \\
\hline Sex & 1 & $4.36946^{* *}$ & $74,314.3^{* *}$ & $8,672.72 * *$ \\
\hline Parity (PAR) & 1 & $.19755^{* *}$ & $8,153.3^{* *}$ & 11.40 \\
\hline Breed $X$ PAR & 17 & $.01233^{* *}$ & $255.9^{\dagger}$ & 5.66 \\
\hline Breed $\times$ YRS & 68 & $.01564 * *$ & $349.9 * *$ & $13.25^{* *}$ \\
\hline Residual & 3,347 & .00717 & 188.2 & 8.75 \\
\hline
\end{tabular}

${ }^{a_{E}}$ Equations for litters, treated as random effects in the model, were absorbed.

${ }^{b}$ Postweaning average daily gain $\mathrm{kg} / \mathrm{d}$.

Age at $100 \mathrm{~kg}$, d.

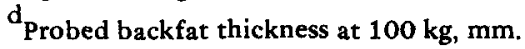

${ }^{\dagger} \mathbf{P}<.10$.

${ }^{* *} \mathrm{P}<01$. 
environmental conditions, conditions which cannot be adequately characterized. In addition, to the extent that sampling contributed to the interaction, such within year-season comparisons are of no interest. The objective of the study was to compare breed performance, necessitating averaging over such effects. In making breed comparisons we therefore assume not only adequate sampling of the breeds, but also that year-seasons were representative of environments to which the population of inference is exposed. These data serve as a caution that the importance of genotype $x$ "physical" environment interactions in swine should not be overlooked.

Probed Backfat. Breed, year-season farrowed, sex and the breed $x$ year-season interaction were all highly significant for probed backfat thickness (table 3). Gilts averaged $25.2 \pm .1 \mathrm{~mm}$ probed backfat, whereas barrows averaged 28.5 $\pm .1 \mathrm{~mm}$.

Despite many changes in ranking of breeds in different year-seasons, certain consistent results were observed. Ranking of the three sire breed groups mated to Yorkshire-Landrace dams was consistent from one year-season to the next and, for all practical purposes, consistent for sire breeds mated to LandraceSpotted dams. Duroc-Landrace $\times$ YorkshireSpotted pigs were the leanest four-breed cross pigs in all but the first year-season. Comparisons between purebred breeds of sire mated to the same breed of dam revealed that Landrace-sired pigs were fatter than the alternative purebredsired pigs for each breed of dam-year-season subclass (i.e., Landrace $\times$ Duroc-Yorkshire pigs were fatter than Spotted $\times$ Duroc-Yorkshire pigs each year-season, et cetera). Similarly,
Duroc-sired pigs were leaner than the alternative-sired pigs for each breed of damyear-season subclass.

Breed group means for probed backfat thickness are presented in table 4. Averaged over year-seasons, comparison of three-breed cross probed backfat means indicated no breed of sire $x$ breed of dam interaction. In pairwise comparisons between pure breeds of sire for the different types of dam, sire breeds ranked Duroc, Yorkshire, Spotted and Landrace from leanest to fattest.

A comparison of average probed backfat of all purebred-sired pigs vs crossbred-sired pigs yielded no significant differences either overall, or in any individual year-season's data. Opposite signs on significant specific differences (table 5) resulted in a small nonsignificant overall estimate. Joint paternal heterosis and recombination effects were estimated to be significantly different from zero in 6 of 30 breed of dam $x$ year-season subclasses, apparently at random (once in each year-season, involving all but one dam breed group and with four positive and two negative differences). It seems likely, therefore, that observed differences were due to chance.

Age at $100 \mathrm{~kg}$. In addition to breed, sex, year-season and the breed $x$ year-season interaction, parity was also highly significant for age at $100 \mathrm{~kg}$, and the breed $\times$ parity interaction approached significance (table 3 ). Barrows averaged $9.7 \mathrm{~d}$ younger at $100 \mathrm{~kg}$ than gilts (178.3 vs $188.0 \pm .5 \mathrm{~d})$. Pigs from second parity sows averaged $6.3 \mathrm{~d}$ younger at $100 \mathrm{~kg}$ than those farrowed in gilt litters $(180.0 \pm .7$ vs $186.3 \pm .6 \mathrm{~d}$ ).

Breed group least-squares means, averaged

TABLE 4. GENERALIZED LEAST-SQUARES MEANSa FOR PROBED BACKFAT THICKNESS BY BREED GROUP

\begin{tabular}{|c|c|c|c|c|c|c|}
\hline \multirow{2}{*}{$\begin{array}{l}\text { Breeding of } \\
\text { sire }\end{array}$} & \multicolumn{6}{|c|}{ Breeding of dam ${ }^{b}$} \\
\hline & D-Y & $D-L$ & D-S & $Y-L$ & $\mathrm{Y}-\mathrm{S}$ & L-S \\
\hline Duroc (D) & & & & 25.13 & 24.95 & 25.65 \\
\hline Yorkshire (Y) & & 27.40 & 25.97 & & & 26.73 \\
\hline Landrace (L) & 28.11 & & 28.10 & & 27.39 & \\
\hline Spotted (S) & 27.20 & 27.63 & & 26.92 & & \\
\hline Crossbred & 27.77 & 27.13 & 27.34 & 27.61 & 25.39 & 27.22 \\
\hline
\end{tabular}

\footnotetext{
${ }^{\mathrm{a}}$ Standard error, average .39 , range .33 to $.50 \mathrm{~mm}$.

${ }^{b}$ Reciprocal crosses combined (i.e., D-Y represents $D \times Y$ and $Y \times D$ ). For each dam breed group, crossbred boars represented $F_{1}$ 's involving the two breeds not included in the $F_{1}$ dam.
} 
across year-seasons, are presented in table 6. As with probed backfat thickness, three-breed cross means suggested no breed of sire $x$ breed of dam interaction. Pairwise comparisons of purebred sires within breed of dam ranked sire breeds Yorkshire, Landrace, Duroc and Spotted from youngest to oldest for age of progeny at $100 \mathrm{~kg}$.
Two estimates of paternal heterosis and recombination effects for age at $100 \mathrm{~kg}$ approached significance, with one suggesting a positive effect, the other a negative effect (table 5). The Yorkshire-Spotted breed of sire estimate reflected a large difference among gilts in only one year-season. The Duroc-Landrace breed of sire estimate reflected significant differences for

TABLE 5. PATERNAL HETEROSIS AND RECOMBINATION EFFECTS

\begin{tabular}{lccc}
\hline $\begin{array}{l}\text { Breeding of } \\
\text { sireb }\end{array}$ & ADGc & AGEd & BFe $^{\mathrm{d}}$ \\
\hline $\begin{array}{l}\text { Landrace-Spotted } \\
\text { Yorkshire-Spotted }\end{array}$ & .015 & -1.81 & .11 \\
Yorkshire-Landrace & .020 & $-3.72^{\dagger}$ & .39 \\
Duroc-Spotted & .016 & -2.11 & $-.89^{*}$ \\
Duroc-Landrace & -.001 & .35 & $1.58^{* *}$ \\
Duroc-Yorkshire & -.021 & -.12 & $-.78^{\dagger}$ \\
SEf & -.004 & 2.11 & $1.03^{*}$ \\
Overall & .013 & -.10 & .45 \\
SEg & .000 & .86 & $.31^{\dagger}$ \\
\hline
\end{tabular}

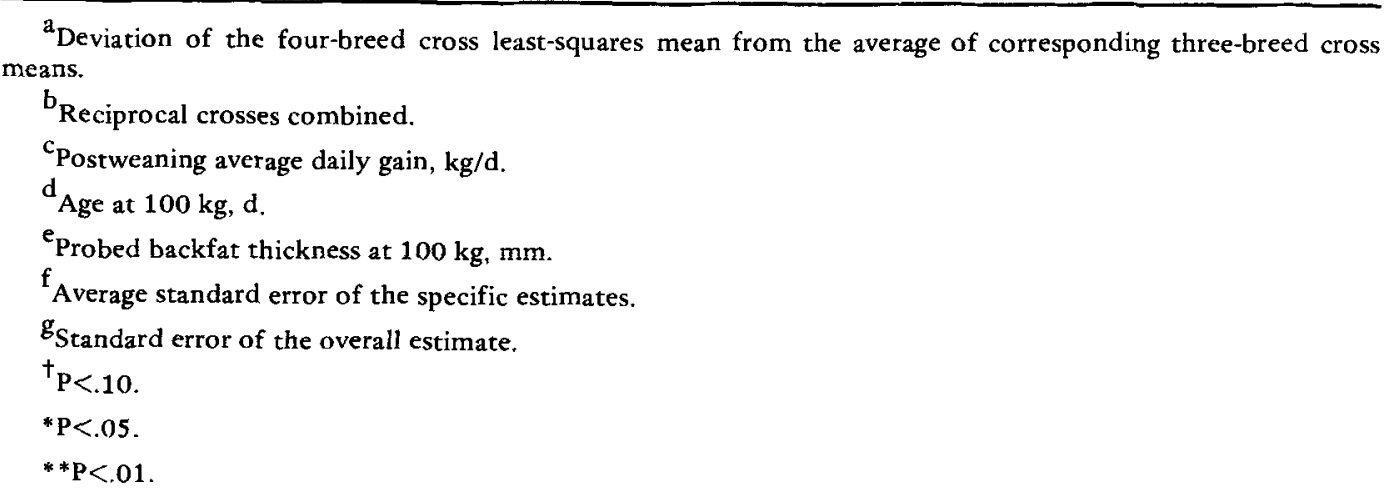

TABLE 6. GENERALIZED LEAST-SQUARES MEANS FOR AGE AT $100 \mathrm{KG}^{\mathrm{a}}$ BY BREED GROUP

\begin{tabular}{|c|c|c|c|c|c|c|}
\hline \multirow{2}{*}{$\begin{array}{l}\text { Breeding of } \\
\text { sire }\end{array}$} & \multicolumn{6}{|c|}{ Breeding of dam ${ }^{b}$} \\
\hline & $D-Y$ & D-L & D-S & $\mathrm{Y}-\mathrm{L}$ & $\mathrm{Y}-\mathrm{S}$ & L-S \\
\hline Duroc (D) & & & & 180.3 & 184.4 & 184.7 \\
\hline Yorkshire (Y) & & 183.3 & 179.6 & & & 181.3 \\
\hline Landrace (L) & 178.6 & & 181.4 & & 183.1 & \\
\hline Spotted (S) & 190.0 & 186.7 & & 184.5 & & \\
\hline Crossbred & 182.5 & 181.3 & 181.3 & 182.7 & 187.7 & 182.9 \\
\hline
\end{tabular}

\footnotetext{
${ }^{\mathrm{a}}$ Standard error, average 1.8 , range 1.5 to $2.3 \mathrm{~d}$.

${ }^{b}$ Reciprocal crosses combined (i.e., D-Y represents $D \times Y$ and $Y \times D$ ). For each dam breed group, crossbred boars represented $F_{1}$ 's involving the two breeds not included in the $F_{1}$ dam.
} 
gilt and sow litters in different year-seasons. However, this estimate was positive, in contrast to most other specific estimates, and the overall difference was not significant.

Average Daily Gain. Breed, year-season, sex and parity were all highly significant for postweaning average daily gain, as were the breed $x$ year-season and breed $x$ parity interactions (table 3). Barrows grew $.075 \mathrm{~kg} / \mathrm{d}$ faster than gilts. Pigs born to second parity sows gained significantly $(.031 \mathrm{~kg} / \mathrm{d})$ faster than those farrowed in gilt litters $(.713 \pm .004$ vs .682 $\pm .003 \mathrm{~kg} / \mathrm{d}$ ).

As breeds ranked differently for rate of gain, both in different year-seasons and across parities, additional analyses were conducted by parity. Breed, year-season, sex and the breed $x$ year-season interaction were highly significant for both parities. Yorkshire $x$ LandraceSpotted and Yorkshire-Spotted $x$ DurocLandrace were the only breed groups for which pigs farrowed in gilt litters had faster postweaning rate of gain than those farrowed by second parity sows. The reverse was true for the other 16 breed groups. Change in rank of the Landrace $\times$ Duroc-Yorkshire was particulary noticeable between parities (from 15th in parity one to 1 st in parity two). If sire breed ranks within breed of dam were considered, rank changes across parities were evident for all but the Yorkshire-Spotted dams. Considering only purebred sire breeds, however, the only rank change occurred between Duroc- and Yorkshire-sired pigs with Landrace-Spotted dams. As well as rank changes, differences between breed groups were in many cases of different magnitudes for the two parities. For example, Landrace- and Spotted-sired pigs by
Duroc-Yorkshire gilts had similar growth rates, but for second parity sows these breed groups represented the extremes of the range in breed average daily gain least-squares means. The breed $x$ parity interaction was also apparent if dam breed rankings within purebred sire breed groups were compared. Dam breeds mated to Duroc and Spotted sires ranked the same in both parities, but this was not the case for Yorkshire or Landrace sires.

Despite significant interactions, breed group means averaged across year-seasons and parities are presented in table 7. Pairwise comparisons among three-breed cross means by breed of dam ranked sire breeds Yorkshire, Duroc, Landrace and Spotted from fastest to slowest for postweaning rate of gain of progeny. The same result was obtained for pigs farrowed in gilt litters. However, a breed-of-sire $x$ breed-ofdam interaction was evident in parity two means, with Duroc sires ranking inconsistently. These results for Spotted sires are at variance with those obtained from the purebred and $F_{1}$ phase of this experiment, in which Spottedsired pigs gained almost as well as the fastest gaining sire breed group, the Duroc (McLaren et al., 1987).

Postweaning average daily gain of crossbred-sired pigs from second parity litters was not found to be significantly different from that of purebred-sired second parity litter pigs in any year-season's data, or overall. For pigs farrowed in gilt litters, significant differences in growth rate were found in two year-seasons. Crossbred-sired pigs farrowed in the spring of 1978 grew significantly faster than purebredsired pigs. However, the reverse was true for pigs born in the fall of 1979 , the three-breed

TABLE 7. GENERALIZED LEAST-SQUARES MEANS FOR POSTWEANING AVERAGE DAILY GAINª BY BREED GROUP

\begin{tabular}{|c|c|c|c|c|c|c|}
\hline \multirow{2}{*}{$\begin{array}{l}\text { Breeding of } \\
\text { sire }\end{array}$} & \multicolumn{6}{|c|}{ Breeding of damb } \\
\hline & $D-Y$ & D-L & D-S & $\mathrm{Y} \cdot \mathrm{L}$ & Y-S & L-S \\
\hline Duroc (D) & & & & .723 & .698 & .689 \\
\hline Yorkshire (Y) & & .703 & .719 & & & .708 \\
\hline Landrace (L) & .716 & & .703 & & .681 & \\
\hline Spotted (S) & .665 & .677 & & .690 & & \\
\hline Crossbred & .707 & .710 & .704 & .706 & .668 & .694 \\
\hline
\end{tabular}

\footnotetext{
${ }^{a}$ Standard error, average .011 , range .009 to $.014 \mathrm{~kg} / \mathrm{d}$.

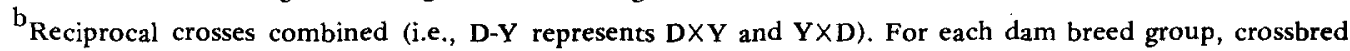
boars represented $F_{1}$ 's involving the two breeds not included in the $F_{1}$ dam.
} 
cross pigs gaining significantly faster than the four-breed cross pigs. Overall, no significant difference was detected between growth rate of purebred-and crossbred-sired pigs (table 5).

\section{Discussion}

These results indicated no real differences between four-breed cross and the average of corresponding three-breed cross means for feed efficiency, postweaning growth rate, or for age and probed backfat thickness at $100 \mathrm{~kg}$. Assuming Dickerson's $(1969,1973)$ parameterization of crossbreeding performance, this difference involves paternal heterosis plus onequarter of the recombination effect. Assuming paternal heterosis to be zero (and there is no theoretical basis to assume otherwise for the traits investigated), these data suggest the recombination effect to be negligible for postweaning performance traits. Recombination effects result from segregation and recombination of genes brought together in the $F_{1}$. Such effects are generally assumed to be negative, reflecting disruption of favorable combinations of various gene pairs established as adaptations to specific environments during breed development. Where breeds are adapted to similar environments, as may be argued to be the case for United States breeds of swine, epistatic recombination losses might be expected to be negligible.

Results obtained in this study are in agreement with the concensus of published reports. Rempel et al. (1964) found pigs sired by crossbred boars to be significantly fatter and slower gaining than those sired by purebred boars. However, the purebred boars used were selected for decreased backfat and increased average daily gain, whereas crossbred boars were chosen at random. Lishman et al, (1975) reported no significant difference between average daily gain and feed-to-gain ratio for pigs sired by Large White vs Large White $x$ Landrace boars. Fahmy and Holtmann (1977), compared Landrace $X$ Yorkshire, Duroc $X$ Yorkshire and Duroc $\times$ Lacombe boars to boars of the four pure breeds and found negligible differences for growth rate between purebred- and crossbred-sired progeny. Kennedy and Conlon (1978) found that progeny of Hampshire $x$ Duroc boars performed similarly to those sired by purebred Hampshire and Duroc boars.

The perception that crossbred boars will increase variability among progeny (relative to purebred-sired pigs) has existed in the past (Fahmy and Holtmann, 1977). While the residual mean square from analysis of fourbreed cross data in this study was greater than that for the entire (three- and four-breed cross) data set for postweaning rate of gain $(.0074 \mathrm{vs}$ $.0056 \mathrm{~kg}^{2} / \mathrm{d}^{2}$ ), the reverse was true for age and probed backfat at $100 \mathrm{~kg}$. For these traits the four-breed cross residual mean squares were $189 \mathrm{~d}^{2}$ and $9.8 \mathrm{~mm}^{2}$, respectively, vs $216 \mathrm{~d}^{2}$ and $10.8 \mathrm{~mm}^{2}$ for the entire data set. A number of researchers have also reported little difference in variability of three- vs four-breed cross pigs (Rempel et al., 1964; Lishman et al., 1975; Fahmy and Holtmann, 1977).

Although crossbred boars have not been shown to affect adversely progeny performance, there is evidence of an advantage in conception rate from using young crossbred vs purebred boars for natural service mating (Wilson et al., 1977; Anderson et al., 1981). This advantage is most likely attributable to earlier sexual maturity in crossbred boars (Conlan and Kennedy, 1978; Buchanan and Johnson, 1984). Hybrid boars might, therefore, prove advantageous in a production situation that uses young boars. In order to improve overall production efficiency, however, the advantage must at least offset the costs of maintaining an additional purebred in the system.

\section{Literature Cited}

Anderson, J. H., H. I. Sellers and K. A. Barber. 1981. Reproductive performance of purebred and crossbred boars in commercial herds. J. Anim. Sci. 53(Suppl. 1):133.

Buchanan, D. S. and R. K. Johnson. 1984. Reproductive performance for four breeds of swine: Crossbred females and purebred and crossbred boars. J. Anim. Sci. 59:948.

Conlon, P. D. and B. W. Kennedy. 1978. A comparison of crossbred and purebred boars for semen and reproductive characteristics. Can. J. Anim. Sci. 58:63.

Dickerson, G. E. 1969. Experimental approaches in utilizing breed resources. Anim. Breed. Abstr. 37:191.

Dickerson, G. E. 1973. Inbreeding and heterosis in animais. In: Proc. Anirnal Breeding and Genetics Symp. in Honor of J. L. Lush. pp 54-77. Amer. Soc. Anim. Sci.-Amer. Dairy Sci. Assoc., Champaign, IL.

Fahmy, M. H. and W. B. Holtmann. 1977. Evaluation of three- and four-breed cross litters and pigs sired by purebred and crossbred boars. Anim. Prod. 24:261.

Gaugler, H. R., D. S. Buchanan, R. L. Hintz and R. K. 
Johnson. 1984. Sow productivity comparisons for four breeds of swine: Purebred and crossbred litters. J. Anim. Sci. 59:941.

Harvey, W. R. 1982. Mixed model capabilities of LSML76. J. Anim. Sci. 54:1279.

Hayenga, M., V. J. Rhodes, J. A. Brandt and R. E. Deiter. 1985. The U.S. Pork Sector: Changing Structure and Organization. Iowa State Univ. Press, Ames.

Hutchens, L. K., R. L. Hintz and R. K. Johnson. 1982. Breed comparisons for age and weight at puberty in gilts. J. Anim. Sci. 55:60.

Johnson, R. K. 1980 . Heterosis and breed effects in swine. North Central Regional Pub. No. 262.

Joyner, S. P. (Ed.) 1983. SUGI Supplemental Library User's Guide. SAS Institute, Inc., Cary, NC.

Kennedy, B. W. and P. C. Conlon. 1978. Comparison of crossbred and purebred boars for progeny growth and carcass merit. Anim. Prod. 27:29.

Lishman, W. B., W. C. Smith, M. Bichard and R.
Thompson. 1975. The comparative performance of purebred and crossbred boars in commercial pig production. Anim. Prod. 21:69.

McLaren, D. G. 1985. Growth performance and crossbreeding system efficiency for four breed of swine. Ph.D. Thesis. Oklahoma State Univ., Stillwater.

McLaren, D. G., D. S. Buchanan and R. K. Johnson. 1987. Individual heterosis and breed effects for postweaning performance and carcass traits in four breeds of swine. J. Anim. Sci. 64: 83.

Rempel, W. E., R. E. Comstock and F. D. Enfield. 1964. Comparison of performance and crossbred pigs sired by purebred and crossbred boars. J. Anim. Sci. 23:87.

Wilson, E. R., R. K. Johnson and R. P. Wetterman. 1977. Reproductive and testicular characteristics of purebred and crossbred boars. J. Anim. Sci. 44:939. 